Western University

Scholarship@Western

Visual Arts Publications

Visual Arts Department

2002

\title{
The Science behind Francesco Borromini's Divine Geometry
}

John G. Hatch

The University of Western Ontario, jhatch@uwo.ca

Follow this and additional works at: https://ir.lib.uwo.ca/visartspub

Part of the Ancient, Medieval, Renaissance and Baroque Art and Architecture Commons, and the Visual Studies Commons

Citation of this paper:

Hatch, John G., "The Science behind Francesco Borromini's Divine Geometry" (2002). Visual Arts Publications. 4.

https://ir.lib.uwo.ca/visartspub/4 


\title{
The Science Behind Francesco Borromini's Divine Geometry
}

\author{
JOHN G. HATCH ${ }^{*}$
}

\section{Introduction}

The popular notion of religion and science being at opposite poles within the intellectual currents of the seventeenth century is challenged by the designs and architectural iconography underlying the churches of Francesco Borromini (1599-1667). Described as something of a licentious eccentric by Gian Lorenzo Bernini and his contemporaries,' Borromini nonetheless relied upon a complex geometric system in his architectural designs, which ruled both the layout and elevation of his buildings. In turn, this use of geometry also seems to have had an important theological justification, namely that of stressing the underlying divine order of the universe whose existence or revelation can only be perceived by the faithful. In essence, this is simply a restatement of the Medieval idea of "God as Divine Geometer" except that, for Borromini, God is no longer depicted in the garb of scholastic rationalism, but rather, as I will show, of seventeenthcentury scientific rationalism: a rationalism that embraces the notion of divine revelation. Although Borromini's interest in ancient mathematics and geometry, as well as his interest in the work of Galileo, are commonly known, one potential source for the archirect's interest in divine geometry and cosmology has yet to be acknowledged fully. It is specifically in the writings of Johannes Kepler that one finds the most consistent explanation for Borromini's use of geometry in architecture, as well as a source for the unusual cosmological Trinitarian references found at the churches of $S$. Carlo alle Quattro Fontane (Rome: 1638-41) and S. Ivo della Sapienza (Rome: begun 1642). ${ }^{2}$

\section{S. Carlo alle Quattro Fontane}

Upon entering the church of S. Carlo, it would appear preposterous even to suggest the existence of a geometrical scheme (Figure 1). Our first impression of the interior is of a flowing, almost dizzying, sense of movement. The walls are composed of shallow and deep curved bays all linked by straight horizontal elements. The whole interior surface is articulated by columns set into walls, while the surfaces themselves are pierced by a series of niches of varying sizes, adding yet another rhythmic dimension. All these elements combine to create a sense of spatial plasticity, serving to dematerialize any notion of architectural solidity. This interior has been described by various architectural historians as "willfully complex", producing a "rolling, rocking effect", "a delightful confusion", etc., all epitomizing Heinrich Wölfflin's characterization of the Baroque's "wild desire for movement." In fact, this interior is so complex that countless interpretations, many

Department of Visual Arts, University of Western Ontario, London, Ontario CaNADA N6A 5B7.jhatch@uwo.ca 
contradictory, have been set forth to explain the design logic of the interior. in spite of the existence of Borromini's drawings.'

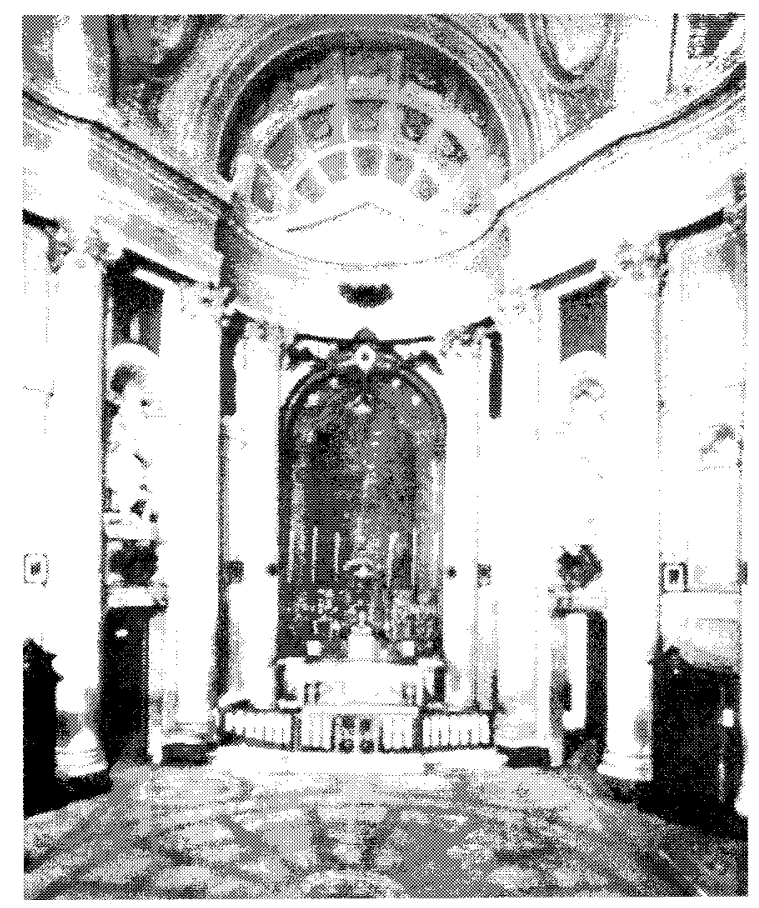

Figure 1. Altar wall, S. Carlo alle Quattro Fontane, Rome, 1638-41 (W. Swaam)

The dizzying character of the interior and, potentially, the diversity of interpretations offered by scholars, simply reflects the intentions of the architect. The main body of the interior is meant to confuse and destabilize one's sense of spatial orientation. There is no ideal viewpoint, but rather a multiplicity of viewpoints which, as a totality, are not meant to exhibit a coherent whole. However, despite this apparent a mbiguity and "willful complexity," the ground plan is nonetheless based on a series of rather simple geometric manipulations. Borromini's preliminary drawings (Figure 2) reveal that the church interior is structured upon two equilateral triangles sharing a common side, with two circles inscribed within them. The two circles are combined to form an oval, describing the area of the dome. The longitudinal chapels are defined by the end points of the two triangles, while the lateral chapels are marked out by the shared corners of the triangles. Finally, the four piers of the church are defined by crossing diagonals originating from the shared corners of the two triangles, cutring the centre of the circles. In this manner, the layout of the building is based on two triangles and two circles circumscribed by an oval. 


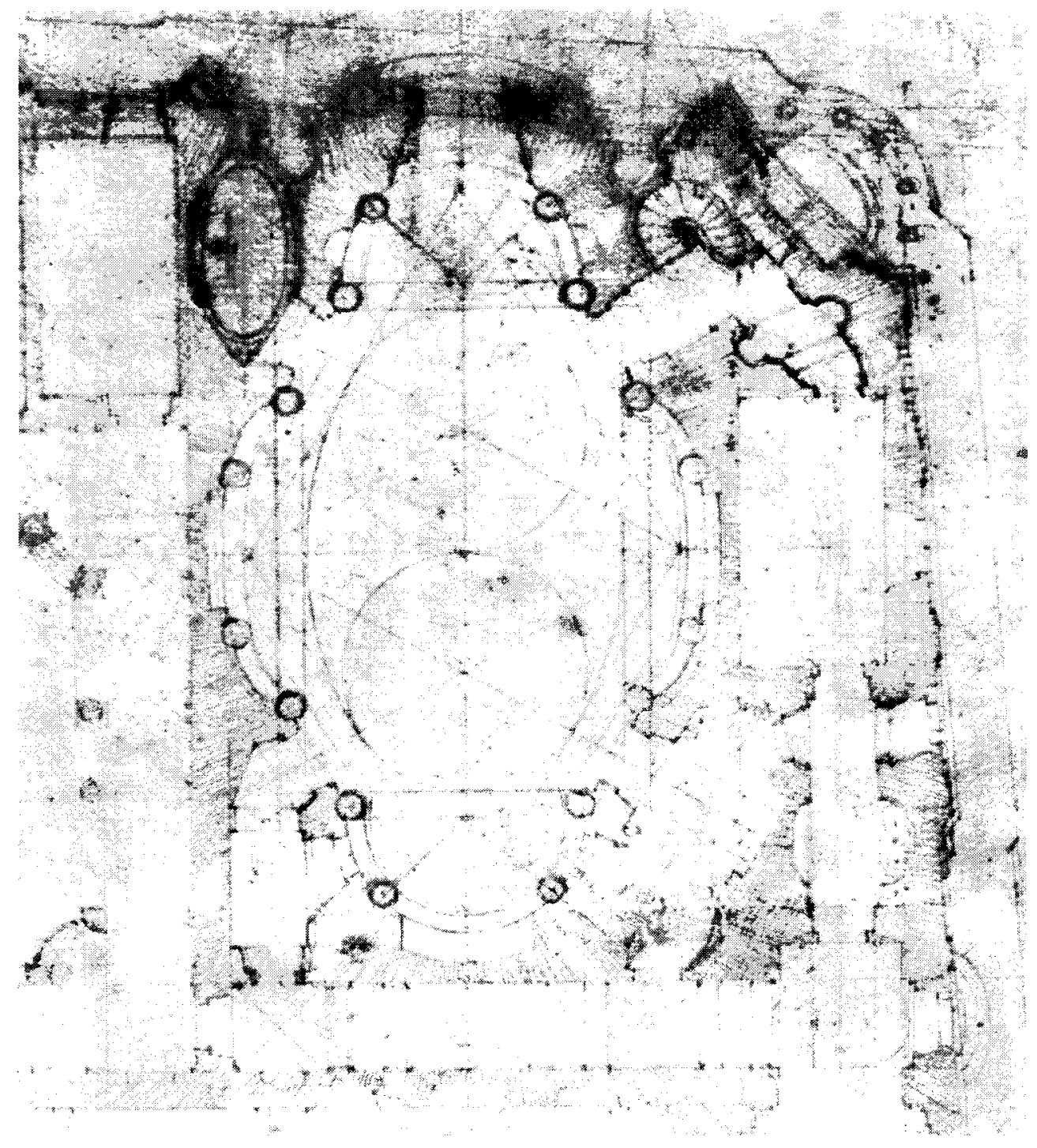

Figure 2. Plan, S. Carlo alle Quattro Fontane, Rome. Detail of drawing (Albertina, Vienna, 173) 




Figure 3. Dome, S. Carlo alle Quattro Fontane, Rome (W. Swaam) 
What then are we to make of this paradoxical relationship between the actual appearance of the interior and its underlying geometrical skeleton? The answer to this query is partially revealed in the upper half of the church and, specifically, the oval dome (Figure 3). The shape of the dome represents the essential underlying scheme of the lower part of the church, complemented by the decorative motifs found in the coffering; in essence, the upper half of the church represents a synopsis of the lower half. At this level of the church, one reaches the point of divine revelation, where the complexity of the forms below are clarified through a process of religious enlightenment. The dome space is clearly meant to be understood as a metaphorical representation of the heavenly realm, which is explicitly shown in the lantern where we find the symbol of the Holy Spirit and behind it a series of rays depicting the spiritual light of revelation. ${ }^{5}$ This light is complemented by the natural light that emanates from the windows at the base of $t$ he dome, making this area the most brightly lit space in the whole church and, consequently, reinforcing the notion of a progression from temporal reality towards the perfection of the heavenly sphere, through the process of spiritual revelation.

A similar reading emerges with regards to the church of S. Ivo della Sapienza, which Rudolf Wittkower describes as symbolizing a "movement downward from the chastity of forms in the heavenly zone to the increasing complexity of the earthly zone." Thus at $S$. Ivo we should find a similar symbolic program as we saw at $S$. Carlo, but with certain modifications more ideally suited to the church of the future University of Rome.

\section{S. Ivo della Sapienza}

The interior of S. Ivo is as confused as that at S. Carlo (Figure 4). Borromini presents another complex fusion of architectural forms serving to create a sort of amorphic structure. Though the central space is essentially circular, it is composed of six bays, three of which are semi-circular, and three others of an irregular shape. The wall surfaces are articulated by a series of niches and a string course serving to divide the wall into two sections. Instead of columns, we find at $S$. Ivo the use of pilasters, distributed in a complex rhythm, which are in turn combined with a series of broken pilasters. On the ground level then, this interior serves to create a similar sense of spatial disorientation as that found at S. Carlo. And like S. Carlo, we also find at S. Ivo a controlling, geometrical skeleton underlying this plan (Figure 5).

As was the case with S. Carlo, the key to understanding the geometry of design at $S$. Ivo lies in the dome area (Figure 6). Standing in the centre of S. Ivo, our eye is gradually led upwards towards the dome. Again we find expressed a process of design clarification where, at one level, the entablature partially reveals the geometric structure, which in turn is further clarified as our eye moves along the vertical ribbing of the dome towards its apex. The whole underlying order is beautifully unfolded in a very gradual process, finally culminating in the figure of the Holy Spirit bathed in a symbolic representation of divine light. As is the case with S. Carlo, we are in the presence of the vault of heaven at S. Ivo, punctuated by the stars decorating the dome and the two superimposed circles formed by the Cherubim and Seraphim. 


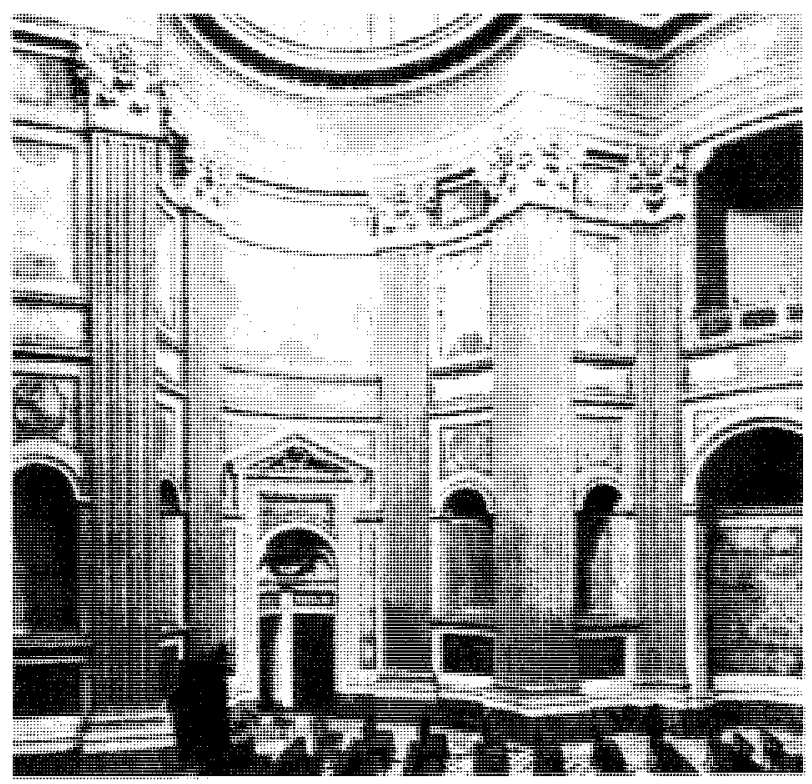

Figure 4. Entrance and left wall, interior, S. Ivo della Sapienza, Rome

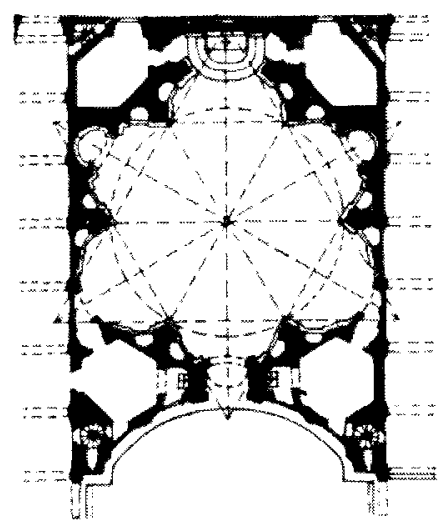

Figure 5. Plan, S. Ivo della Sapienza, Rome

Borromini's use of geometry has always been puzzling. Comparing his architecture with that of Palladio, we observe that where Palladio's use of geometry is explicitly demonstrated in the final structure, Borromini's still remains implicit to a large extent. Even in the buildings of such contemporaries as Bernini, the geometry of design is still evident in controlling the unfolding of his structures. In Borromini's case, geometry is 
not necessarily meant to only generate form, but also remains an implicit justification of the building as a whole. It becomes a sort of hidden dimension, disguised by a profusion of structural and decorative manipulations.

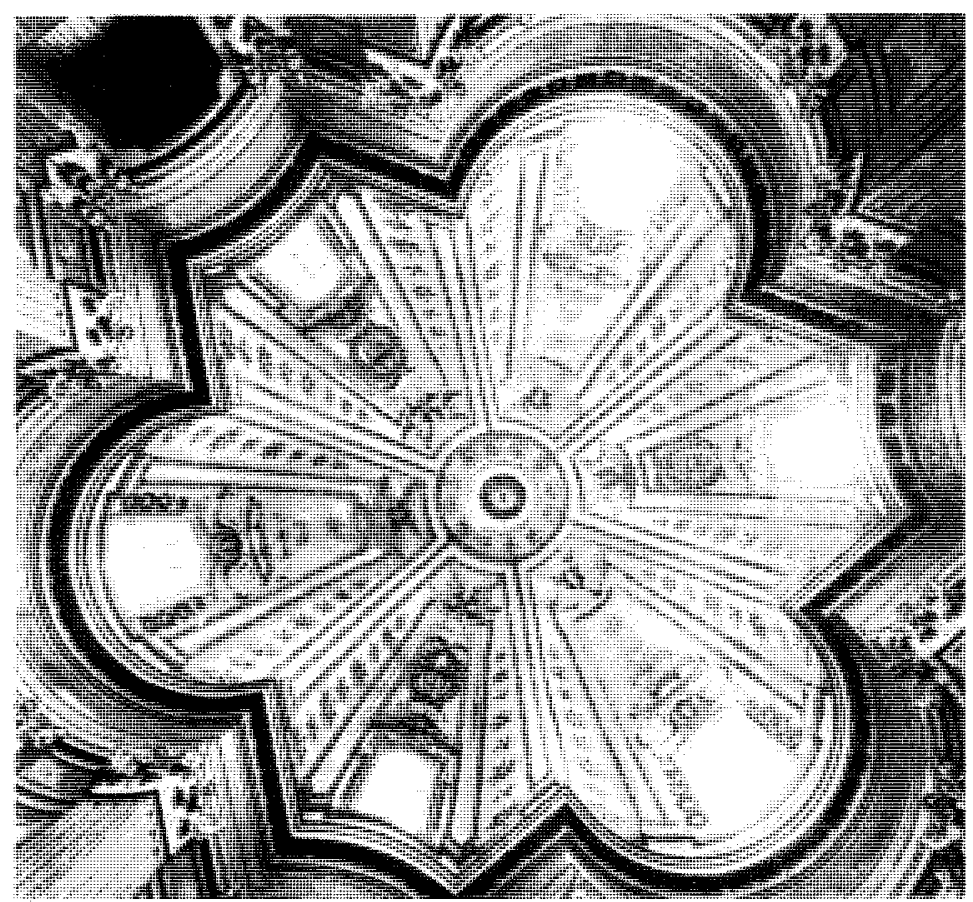

Figure 6. Interior of the Dome, S. Ivo della Sapienza, Rome

\section{Borromini and Kepler's geometric universe}

To my mind, the parallels are difficult to avoid berween Borromini's use of geometry and the role geometry plays in the work of Johannes Kepler (1571-1630). Kepler's primary goal was to discover the invisible skeleton of the universe; a skeleton that Kepler believed to be geometric (Figure 7). In fact, for Kepler, the eternal and ultimate truths of the universe are based on a "divine geometry". More importantly, geometry becomes a principle link between the human and the divine. According to Kepler, God endowed "man" with an understanding of geometry, providing him with the tools to deduce a priori the whole blueprint of the universe and, through this process, come in contact with the mind of God." In Borromini's case a similar interpretation emerges. The churches of $\mathrm{S}$. Carlo and S. Ivo represent, in a sense, a microcosm of the universe; the lower storeys reflecting nature in its apparent haphazard and accidental form, the upper storeys representing the divine in its simplicity and perfection. But the lower storeys of S. Ivo, 


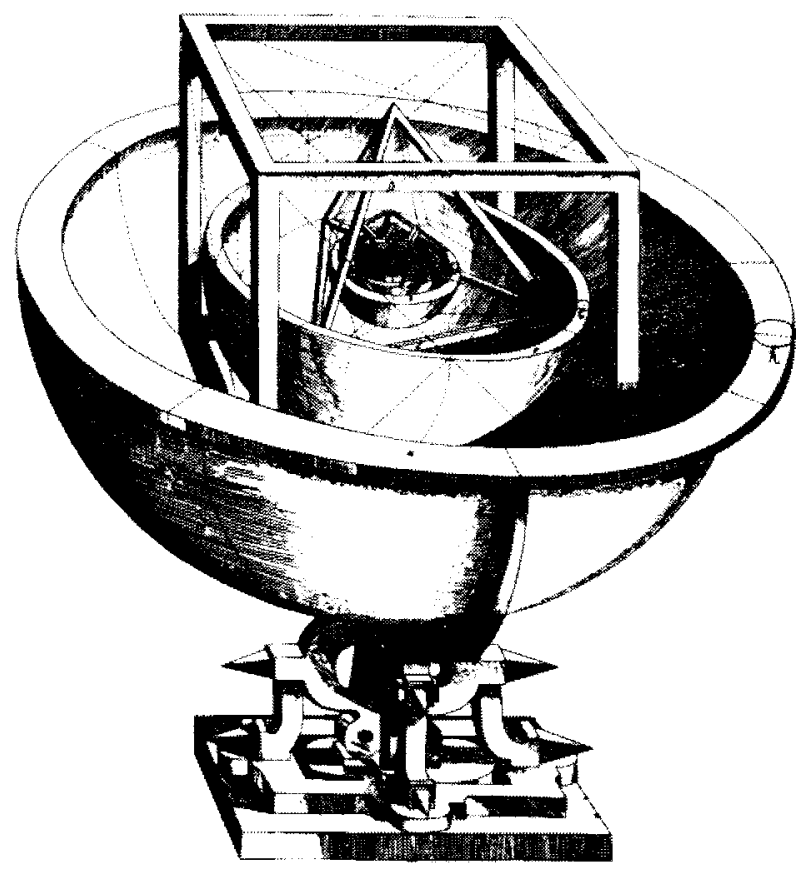

Figure 7. Nested sphere model of the solar system, Johannes Kepler, Mysterium Cosmographicum (1596)

and particularly S. Carlo, as accidental and haphazard as they may appear, are, as pointed out above, nonetheless conceived and ruled by a strictly organized geometric system, echoing the inherent skeleton of the universe as a whole. In this manner, Borromini recreates nature in its complexity, while in his designs he supplies by analogy, obviously, its underlying order: a divine order ruling an apparent chaos, as Kepler expressed it, and as Galileo spoke of when he wrote that, "...the great book of nature...is written in the language of mathematics, and its characters are triangles, circles and other geometrical figures without which it is humanly impossible to understand a single word of it." 10 This idea of a hidden order may explain why Borromini guarded his plans so adamantly. "It is most likely that Borromini did not want to reveal the geometric underpinnings of his buildings largely because he expected the viewer to undertake, unassisted, the process of decoding the substructure of his buildings in a manner analogous to that outlined by Kepler; to become, as Kepler puts it, "the priests of God, called to interpret the Book of Nature."

The contrast of geometric complexity dictating the lower zones of Borromini's churches and the geometric simplicity of the upper zones is meant to reflect the apparent 
imperfections of the terrestrial versus the perfection of the heavenly realm. Such a contrast does not exist in the churches of Borromini's contemporaries, where geometric clarification rules throughout despite the proliferation of decoration. In Borromini's case, we are witnessing a strong debt to Neoplatonic philosophy; a philosophy which serves as a foundation for modern science, and which influenced extensively the work of Michelangelo whom Borromini admired profoundly. It is Neoplatonism which rules the scientific inquiries of, for example, Nicholas Cusa, Giordano Bruno and Kepler. In fact, the reading of the dialogue between the earthly and the heavenly Borromini establishes at S. Carlo and S. Ivo, is succinctly echoed in Marcellus Palingenius's statement in the Zodiacus vitae (1534) where he posits, "the opposition between the terrestrial and the celestial regions, where the former is imperfect and nothing more than a shadowy reflection of the perfection of the latter." ${ }^{\text {".3 }}$ In sum, Borromini's debt to Neoplatonism plays, in my opinion, a substantial part in his vision of architecture as a microcosmic version (or vision) of the universe, taking on the form of an architectural hieroglyphics dictated by the creator whose interpretation must be pried by the power of reason and observation in order to discover and understand its order, a process whose interpretation can only occur through the contemplation of the divine. It is this same Neoplatonism which might have made Borromini receptive to Kepler's ideas to begin with.

\section{Borromini's cosmology}

With Borromini's religious architecture acting as a microcosm of the universe, it is interesting to note that where the universe of Copernicus (and subsequently Galileo and Kepler) removed the earth from its centre, Borromini shifts away substantially from the classical conception of anthropomorphic architecture. Bernini himself observed that architecture, in its design, depended on the proportions of the human body; what distinguishes Borromini from his contemporaries was the break with this tradition. ${ }^{14}$ Thus as science dislocated man from the centre of the universe, Borromini abandoned the use of the human body as a model for architecture. ${ }^{15}$ But the parallel does not end there. The sun quickly assumed the heralded position at the centre of the universe in science, and with it occurred a theological revision. Where God had previously been situated at the outer realm of the universe, the Baroque saw him introduced, with some welldocumented difficulties, into the centre with the sun as his attribute. This change is reflected in the words of Monsignor Giovanni Battista Agucchi who wrote

God himself may reasonably be designated and recognized as the middle because the created things are outside Him yet always return to Him as do the rivers to the sea. ${ }^{16}$

Kepler echoes these words in the Mysterium Cosmographicum (1596) where, in attempting to justify the placement of the sun at the centre of the universe, he writes,

that the sun must be in the centre of the world because he is the symbol of God the father, the source of light and heat, the generator of the force which drives the planets in their orbits..." 
The sun is significantly the central symbol of the churches of S. Carlo and S. Ivo. Both are crowned by lanterns through which sunlight enters and illuminates the interiors. In the case of $S$. Carlo light acts as a symbol of divine revelation, where the process of design clarification between the lower and upper storeys seems rather sudden, while at S. Ivo light represents divine wisdom, where the movement from the lower to upper story is more gradual.

But both S. Carlo and S. Ivo appear to carry this religious cosmology further. For Kepler, the visible universe as a whole is a symbol of the Triniry. Not only is God represented by and as the sun, but the sphere of the fixed stars represents Christ and the invisible forces emanating from God represent the Holy Spirit. As Kepler himself put it in the Mysterium Cosmographicum:

the Sun in the center, which was the image of the Father, the Sphere of the Fixed Stars, or the Mosaic waters, at the circumference, which was the image of the Son, and the heavenly air which fills all parts, or the space and firmament, which was the image of the Spirit. ${ }^{18}$

Significantly, S. Carlo is co-dedicated to the Trinity, while S. Ivo contains numerous symbolic references to the Trinity, and both contain symbols of the Holy Spirit at the top of their respective domes. S. Ivo also has stars decorating its dome, while at $S$. Carlo we find the presence of an oval dome. The latter is a particularly curious feature since Kepler himself discovered in the Astronomia Nova (1609) that the planets revolve around the sun elliptically rather than in a circular manner." All of these factors seem to further reveal that Borromini was aware of Kepler's cosmology and applied some of its basic ideas to his architecture.

As suggestive as these parallels between Kepler's scientific speculations and Borromini's architectural iconography are, how Borromini became familiar with Kepler's work is difficult to establish in any concrete way. Unfortunately, we know little of Borromini's formal education or what books were collected in his extensive library, nor do we possess any first-hand documents explicitly outlining Borromini's position vis-a-vis science. But we do know this, that Kepler's popularity at the time had definitely reached Italy. He was protected often by the Jesuits (despite the fact that Kepler was Lutheran), was offered the Chair of Mathematics at Bologna, the highest position for an astronomer in Italy, and was nominated to the Academia dei Linceie. ${ }^{20}$ We also find instances recorded of Borromini's contacts with Galileo's students, who could easily have made the architect aware of Kepler's work. ${ }^{21}$ In turn, one cannot ignore the possibility that the patrons of S. Carlo, the Discalced Trinitarians, an order with which Borromini formed a lifelong relationship, may have been attracted to Kepler's rather unique Trinitarian explanation of the cosmos. By whatever means Borromini came to know of Kepler's work, once exposed to it, he would certainly have been attracted to Kepler's unusual geometric and aesthetic approach to astronomy, which was rather unique. ${ }^{22}$ 


\section{Conclusion}

There can be little doubt that both S. Carlo and S. Ivo are microcosmic models of the universe, devised along general Neoplatonic lines, and use geometry to represent the underlying order of that universe. This is further supported by Borromini's belief that most ancient architecture was concerned largely with two things, astronomy and mathematics. ${ }^{23}$ The specific connection to Kepler is, admittedly, more difficult to establish with any certainty. However, in closing, I would like to propose two more links that seem to point to such an intellectual interchange. Kepler believed that the sun was the prime mover of the planets. He was uncertain as to how this actually occurred but speculated that it may be related to magnetism. ${ }^{24}$ Although he was uncertain about the actual material forces at play, in terms of his Trinitarian model, the sun/God acts through the Holy Spirit in moving the planets. Significantly, at S. Carlo, one finds inscribed above the entrance that "the august Trinity is revealed as ruler of the world's circuit, the orbis terrarum", an inscription that is underscored by the fact that the Holy Spirit crowns the dome before a symbolic representation of the sun. At $S$. Ivo, the lantern at the top of the dome is similarly crowned and the church itself is dedicated to the Divina Sapienze"the planet which leads men aright along every parh."

\section{HaRMONICIS LiB. V.}

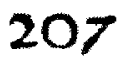

mnia ( nnfinita in pocentiâ) permeantes aClu : id quod aliter à me non potuit exprimi, quam per continuam feriem Notarum interneda-
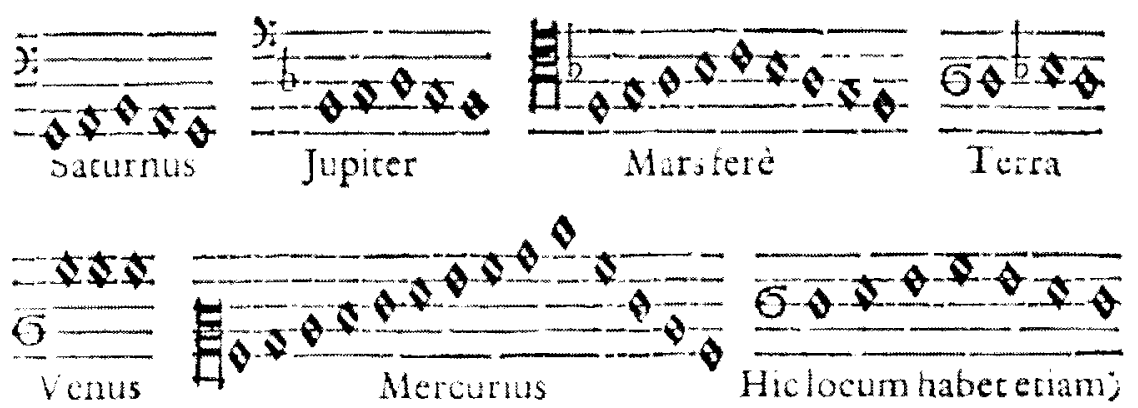

Figure 8. Musical Notation of the Plancts, Johannes Kepler, Harmonice Mundi, 1619

Lastly, one finds a consistent ABA rhythm along the wall surfaces of both S. Carlo and $S$. Ivo, often suggesting the shape of a triangle. This rhythm is most definitely an inference to the Trinity, while also referencing the triangles used in the designs of both $S$. Carlo and S. Ivo, yet it bears a possible connection to one more aspect of Keplerian cosmology. Kepler held fast to the Pythagorean notion of the music of the spheres which he reformulated in his book, Harmonice Mundi (1619). ${ }^{26}$ The earth "sings", as Kepler 
puts it, MI FA MI, which in musical notation (Figure 8) forms a visual analogue to the type of rhythms Borromini produces along the walls of the lower parts of both $\mathrm{S}$. Carlo and S. Ivo. If both churches are dedicated in some form to planetary motion, and echo in their lower storeys the terrestrial realm, as I have argued above, it may not be so far fetched to assume that Borromini has included a musical reference as well.

Obviously, this paper has not exhausted all the links that might exist between Borromini and Kepler. It is hoped that the above speculations have at least pointed to a new and fruitful direction that ultimately complements many of the existing interpretations of S. Carlo and S. Ivo, by adding yet another fascinating wrinkle to the church architecture of Francesco Borromini.

\section{Acknowledgments}

I must thank Ann Marie Carroll, J. Gerard Curtis, Karen Hatch (and the boys), Laurier Lacroix, Jody McNabb, and Irene Mordas, for their invaluable assistance and encouragement during the various stages of research and writing.

\section{Notes}

1. Anthony Blunt, Borromini (London: Penguin Books, Ltd., 1979) pp. 212-213; Lco Steinberg, Borrominis S. Carlo alle Quattro Fontane: A Study in Multiple Forms and Architectu ral Symbolism (New York: Garland Publishing, Inc., 1977) pp. 15-16.

2. Blunt, Borromini, p. 47. Leo Steinberg does hint at a possible connection between Kepler and Borromini, but more in terms of a shared zeitgeist than any direct links; see Steinberg, Borromini's S. Carlo alle Quattro Fontane, pp. 240-241.

3. Steinberg, Borromini's S. Carlo alle Quattro Fontane, pp. 15-16 \& 169; Heinrich Wölfflin, Renaissance and Baroque (London: William Collins Sons \& Co., Ltd., 1984) p. 59.

4. Steinberg, Borromini's S. Carlo alle Quattro Fontane, pp. 18-41.

5. This idea of the dome or vault of heaven may have been inspired by Byzantinc architecture since we known that Borromini was collecting information on the Hagia Sophia and San Vitale in the early 1640s. Joseph Connors, "S. Ivo alla Sapienza: The First Three Minutes," Journal of the Society of Architectural Historians 55 (1996): 50-51.

6. Rudolf Wittkower, Art and Architecture in Italy, 1600-1750 (Harmondsworth: Penguin Books, Ltd., 1973) p. 138.

7. Paolo Portoghesi, The Rome of Borromini: Architecture as Language (Ncw York: George Braziller, 1968) pp. 149-158.

8. Wittkower argues that Borromini's use of geometry represents a move away from "the classical principle of planning in terms of modules." Wittkower, Art and Architecture in Italy, p. 132.

9. Arthur Koestler, The Sleepwalkers (London: Penguin Books, Ltd., 1979) pp. 263-264; Rhonda Martens, Kepler's Philosophy and the New Astronomy (Princeton and Oxford: Princeton University Press, 2000) pp. 32-38 \& 48-51.

10. Cited in Blunt, Borromini, pp. 46-47.

11. Anthony Blunt, "Italy: The Architccture of Rome, Borromini," Anthony Blunt, ed., Baroque and Rococo: Architecture and Decoration (New York: Harper and Row, Pub., 1978) p. 48; Joseph Connors, "A Copy of Borromini's S. Carlo alle Quattro Fontane i n Gubbio," Burlington Magazine 137, 1110 (Sept. 1995): 590. 
12. Cited in Koestler, The Sleepwalkers, p. 264. On the notion of astronomers as priests in Kepler, see Job Kozhamthadam, The Discovery of Kepler's Laws: The Interaction of Science, Philosophy, and Religion (Notre Dame and London: University of Notre Dame Press, 1994) pp. 41-42.

13. Cited in Alexander Koyré, From Closed World to the Infinite Universe (Baltimore and London: The Johns Hopkins University Press, 1957) p. 25.

14. Wittkower, Art and Architecture in Italy, p. 130.

15. It should be noted that Borromini does not sever completely his ties with the anthropomorphic in architecture. One does still find occasional references to parallels between the human body and architecture in Borromini's notes and letters. In turn, when Borromini does reference the human body, he adopts the more organic relationship between the body and architccture defined by Michelangelo. James S. Ackerman, The Architecture of Michelangelo (London: A. Zwemmer, Led., 1966).

16. Cited in Erwin Panofsky, Galileo as Critic of the Arts: Aesthetic Attitude and Scientific Thought (The Hague: Martin Nijhoff, 1954) p. 39.

17. Cited in Koestler, The Sleepwalkers, p. 263.

18. Cited in Martens, Kepler's Philosophy and the New Astronomy, p. 40; Kozhamthadam, The Discovery of Kepler's Laws, pp. 29-34.

19. It will, obviously, be pointed out that the dome at $S$. Carlo is oval rather than elliptical. I suspect that Borromini may have decided that designing an elliptical dome was far too difficult; an oval is much simpler to handle geometrically and does have architectural precedents. It should be noted, however, that Kepler himself had toyed with the idca of planetary motion describing an oval around the sun, but the observational data Kepler inherited from Tycho Brahe simply did not support this. Martens, Kepler's Philosophy and the New Astronomy, pp. 87-90.

20. Koestler, The Sleepualkers, pp. 282, 353-354, 387.

21. Joseph Connors, "S. Ivo alla Sapienza," pp. 50-52.

22. Martens, Kepler's Philosophy and the New Astronomy, pp. 12-13.

23. Stcinberg, Borromini's S. Carlo alle Quattro Fontane, p. 355.

24. Martens, Kepler's Philosophy and the New Astronomy, pp. 83-84.

25. Steinberg, Borromini's S. Carlo alle Quattro Fontane, pp. 316 and 386, n. 49.

26. Johannes Kepler, Epitome of Copernican Astronomy and Harmonies of the World, trans. Charles Glenn Wallis (Amherst, New York: Prometheus Books, 1995) pp. 199-200. 